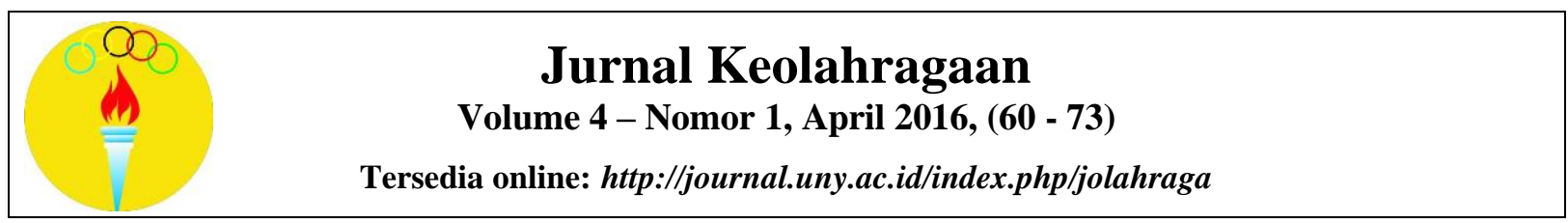

\title{
PENGEMBANGAN MODEL PERMAINAN BOLATANGAN UNTUK ANAK USIA SEKOLAH DASAR KELAS ATAS
}

\author{
Muhamad Abdurrochim ${ }^{1)}$, Hari Amirullah Rachman ${ }^{2)}$ \\ ${ }^{1}$ IKIP PGRI Kalimantan Timur, Jalan Suwandi, Blok.C RT.23, Gn. Kelua, Samarinda Ulu, Kota \\ Samarinda, Kalimantan Timur, Indonesia. Email: muhamadabdurrochim04@gmail.com \\ ${ }^{2}$ Pendidikan Olahraga, Universitas Negeri Yogyakarta. Jalan Colombo No 1, Karangmalang \\ Yogyakarta 55281, Indonesia. Email: harirachman@yahoo.com.au
}

\begin{abstract}
Abstrak
Penelitian ini bertujuan mengembangkan model permainan bolatangan untuk anak sekolah dasar kelas atas. Produk yang dihasilkan CD dan buku. Penelitian ini mencakup tiga tahapan yaitu tahapan validasi kesesuaian dan kualitas model oleh ahli, tahap uji coba skala kecil, dan tahap uji coba skala luas. Penelitian ini dilakukan SD Negeri 1 Petir, SD Negeri 2 Petir, SD Negeri Kembangsari dan MI Sananul Ula, Instrumen yang digunakan adalah kuesioner kesesuaian model dan respon siswa terhadap permainan. Hasil penelitian menunjukkan bahwa para ahli dan guru menilai produk telah sesuai. Pandangan siswa, $100 \%$ permainan dapat dilakukan, menyenangkan dan dapat membuat anak menjadi senang bergerak, 90,82\% memberikan tanggapan bahwa permainan mudah dilakukan, 96,94\% dapat memahami peraturan dengan baik, $93,88 \%$ siswa taat pada peraturan yang berlaku, $10.20 \%$ siswa mengalami kesulitan, 98,98\% siswa merasa suka dengan peralatan yang digunakan, 95,92\% dapat melakukan kerjasama, dan 6,74 \% merasa takut melakukan permainan yang diajarkan.
\end{abstract}

Kata Kunci: pengembangan, bolatangan, sekolah dasar kelas atas

\section{DEVELOPMENT OF HANDBALL GAME MODEL TO UPPER CLASS ELEMENTARY SCHOOL CHILDREN}

\begin{abstract}
This research aimed to develop a hand ball game model to upper class elementary school children. The product result is form guide and CD. This research included of three phase were stability and quality of the model by expert phase, small-scale phase, and large-scale pahse. This research conduct in elementary school 1 Petir, elementary school 2 Petir, elementary school Kembangsari and MI Sananul Ula. The instruments that use were the suitability of the model and the response of students to the game questionnaire. The results showed that the experts and teachers assess product matches. 100\% the game can be done, fun and can make children be happy moving, 90,82\% provide responses that the game is easy to do, 96, $94 \%$ can understand the rules very well, 93,88\% Students obedient to regulations, 10. 20\% students have difficulty, 98,98\% students feel a liking equipment used, 95. 92\% cooperation can do and 6,74\% feared the games taught.
\end{abstract}

Keywords: development, handball, elementary school upper-class.

How to Cite Item: Abdurrochim, M., \& Rachman, H. (2016). Pengembangan model permainan bolatangan untuk anak usia sekolah dasar kelas atas. Jurnal Keolahragaan, 4(1), 60-73. Retrieved from http://journal.uny.ac.id/index.php/jolahraga/article/view/8136 


\section{PENDAHULUAN}

Pendidikan jasmani merupakan pendidikan yang menggunakan aktivitas fisik sebagai media untuk mencapai tujuan yang diharapkan. Salah satu komponen penunjang pelaksana pendidikan jasmani agar dapat berjalan dengan baik adalah kurikulum. Kurikulum merupakan seperangkat rencana dan pengaturan mengenai tujuan, isi dalam bahan pelajaran serta digunakan sebagai pedoman penyelenggaraan kegiatan pembelajaran untuk mencapai tujuan pendidikan nasional yang sesuai dengan kekhasan, kondisi dan potensi daerah suatu pendidikan dan peserta didik.

Mata pelajaran Pendidikan Jasmani, Olahraga dan Kesehatan (Penjasorkes) merupakan salah satu mata pelajaran yang diharapkan mampu mengupayakan untuk mewujudkan manusia seutuhnya yang diselenggarakan di sekolah, baik dari jenjang pendidikan dasar maupun menengah. Pendidikan yang tidak mempunyai sasaran pedagogis dan tidak ada pendidikan yang lengkap tanpa adanya pendidikan jasmani, karena gerak sebagai aktivitas jasmani adalah dasar bagi manusia untuk mengenal dunia dan dirinya sendiri yang secara alamiah berkembang searah dengan perkembangan zaman. Paturusi (2012, p. 4) berpendapat bahwa 'Pendidikan Jasmani dan Olahraga adalah proses pendidikan melalui aktivitas jasmani dan olahraga terpilih untuk mencapai tujuan pendidikan'. Adanya mata pelajaran Penjasorkes merupakan salah satu media untuk mendorong pertumbuhan fisik, perkembangan psikis, keterampilan motorik, pengetahuan dan penalaran, penghayatan nilainilai (sikap-mental-sportivitas-spiritual-sosial) serta pembiasaan pola hidup sehat yang bermuara untuk merangsang pertumbuhan dan perkembangan kualitas fisik dan psikis yang seimbang. Pencapaian tujuan Penjasorkes di sekolah dasar (SD) diharapkan mempertimbangkan tujuan pembelajaran, kemampuan siswa, metode, materi, sarana dan prasarana, aktivitas belajar serta keseimbangan siswa agar proses pembelajaran berjalan dengan baik.

Materi ajar dalam Penjasorkes mempunyai beberapa aspek diantaranya aspek permainan, aspek pengembangan, aspek akuwantik, aspek ritmik, aspek senam atau uji diri, dan aspek kesehatan. Aspek permainan mempunyai persentase terbesar dari pada aspek ajar lainnya. Materi permainan dan olahraga dilakukan secara berpasangan, beregu dan individual. Penilaian mengajarkan nilai kerjasama, sportivitas, keju- juran, toleransi, dan meningkatkatkan rasa percaya diri. Permainan dan olahraga meliputi permainan bola kecil dan permainan bola besar. Permainan bola kecil di antaranya kasti, rounders, softball, dan baseball. Sedangkan permainan bola besar yang diajarkan sepak bola, bola voli, dan bola basket merupakan materi permainan yang diajarkan pada kelas atas atau kelas, 4,5 dan 6.

Materi permainan olahraga bola tangan tidak secara jelas tercantum dalam kurikulum, akan tetapi masih termasuk dalam lingkup permainan bola besar. Permainan bola tangan masih menjadi olahraga pilihan di dalam kurikulum penjasorkes sehingga masih sangat jarang diajarkan di sekolah dasar.

Permainan bola tangan, merupakan salah satu permainan yang diberikan di sekolah dasar. Namun demikian permainan bola tangan yang diajarkan untuk diberikan di sekolah dasar adalah permainan bola tangan yang umumnya dimainkan oleh orang dewasa, nampaknya perlu disesuaikan dengan keadaan anak-anak sekolah dasar. Untuk keperluan itu, dalam judul di atas akan diuraikan tentang permainan bola tangan mini, sebagai usaha menyesuaikan permainan bola tangan yang umum dimainkan oleh orangorang dewasa dikembangkan sesuai dengan kebutuhan anak sekolah dasar. Permainan bola tangan mini dianjurkan diterapkan pada anak sekolah dasar kelas V dan kelas VI. Adapun dalam judul di atas akan mencakup tentang pengertian bola tangan mini, alat dan fasilitas, peraturan permainan serta perwasitan dalam permainan bola tangan mini.

\section{Model Pembelajaran}

Sagala (2012, p.175) mendefinisi-kan model sebagai kerangka konseptual yang digunakan sebagai pedoman dalam melakukan kegiatan. Model dapat dipahami sebagai: (1) suatu tipe atau desain, (2) suatu deskripsi atau analogi, (3) suatu sistem asumsi-asumsi, datadata yang dipakai untuk menggambarkan secara sistematis suatu objek atau peristiwa, (4) suatu desain yang disederhanakan dari suatu sistem kerja, suatu terjemahan realitas yang disederhanakan, (5) suatu deskripsi dari suatu sistem yang mungkin atau imajiner, (6) penyajian diperkecil agar dapat menjelaskan dan menunjukkan sifat aslinya. Menurut Metzler (2011, p.17) model dapat difungsikan sebagai contoh dalam mendemonstrasikan pada orang lain tentang cara lain untuk bertindak atau berpikir. Rosdiani (2012, p. 3) mengemukakan bahwa model adalah repre- 
sentasi dari suatu abstraksi realistis yang dirancang untuk menjelaskan aspek-aspek suatu persoalan atau ruang lingkup persoalan dan dapat menjelaskan hubungan-hubungan yang penting.

Menurut Rahyubi (2012, p. 251) model pembelajaran adalah kerangka konseptual yang digunakan sebagai pedoman dalam melakukan pembelajaran. Model pembelajaran merupakan kerangka konseptual yang melukiskan prosedur yang sistematis dalam mengorganisasikan pengalaman belajar untuk mencapai tujuan belajar. Jadi, model pembelajaran cenderung prespektif (memberi petunjuk dan bersifat menyatukan), yang relatif sulit dibedakan dengan strategi pembelajaran.

Selain memperhatikan hal-hal yang rasional dan teoritis, tujuan dan hasil yang ingin dicapai, model pembelajaran seharusnya memiliki 5 unsur dasar, yaitu: (1) Syntax, adalah langkahlangkah operasional pembelajaran, (2) Social system, adalah suasana dan norma yang berlaku dalam pembelajaran, (3) Principles of reaction, menggambarkan bagaimana seharusnya guru memandang, memperlakukan, dan merespons siswa, (4) Support system, yakni segala sarana, bahan alat atau lingkungan belajar yang mendukung pembelajaran, dan (5) Instructional dan nurturant effects, adalah hasil belajar yang diperoleh langsung berdasarkan tujuan yang disasar (intructional effects) dan hasil belajar di luar yang di sasar (nurturant effects).

Tujuan dan hasil yang ingin dicapai seharusnya memiliki 5 unsur, yaitu: (1) syntax, adalah langkah-langkah untuk mempraktikkan ke siswa bagaimana cara bermain bola tangan, (2) social system, suasana permainan membuat anak mudah mengerti dan bisa dilakukan oleh siswa, (3) principles of reaction, dipandang dari segi permainan. Guru sulit mengenalkan permainan bolatangan karena minimya media pembelajaran bola tangan, dari sinilah dilakukan pengembangan bola tangan dilakukan untuk mempermudah guru dalam mengajarkan kepada siswa siswa langkah-langkah dalam permainan bola tangan sehingga siswa melakukans sesuai dengan yang diharapkan, (4) Support system, sarana disesuaikan dengan lingkungan sekolah, menggunakan bola yang tidak membahayakan siswa, ukuran lapangan yang dirubah, gawang disesuaikan dengan jangkauan siswa dan mudah dilakukan di lingkungan sekolahan. (5) Instructional dan nurturant effects, hasil dari pengenalan ini siswa dapat memainkan atau mempraktikkan permainan sesuai dengan yang diharapkan.

\section{Pendidikan Jasmani, Olahraga dan Kesehatan di Sekolah Dasar}

Penjasorkes merupakan salah satu mata pelajaran yang dilaksanakan pada jenjang sekolah dasar, menengah bahkan pendidikan tinggi. Penjas selalu masuk dalam jenjang pendidikan dari waktu ke waktu yang memberikan kontribusi terhadap pertumbuhan dan perkembangan anak secara menyeluruh melalui pengalaman gerak. Pendidikan jasmani olahraga dan kesehatan merupakan bagian integral dari pendidikan secara keseluruhan, bertujuan untuk mengembangkan aspek kebugaran jasman, keterampilan gerak, keterampilan berfikir kritis, keterampilan sosial, penalaran, stabilitas emosi, tindakan moral, aspek pola hidup sehat dan pengenalan lingkungan bersih melalui aktivitas jasmani, olahraga, dan kesehatan terpilih yang direncanakan secara sistematis, dalam rangka mencapai tujuan pendidikan nasional (BNSP, 2006, p. 1). Rosdiani (2012, p. 25) berpendapat bahwa "penjas adalah bagian penting dari pendidikan, melalui pendidikan jasmani yang diarahkan dengan baik, anak-anak akan mengembangkan keterampilan yang berguna bagi pengisian waktu senggang terlibat dalam aktivitas yang kondusif untuk mengembangkan hidup sehat, berkembang secara sosial dan menyumbang pada kesehatan fisik dan mentalnya". Menurut Pill dkk (2012, p. 123), olahraga memiliki dua prinsip mengajar yaitu olahraga dalam pendidikan jasmani dapat meningkatkan akses siswa untuk bergerak dan memunculkan ide-ide yang positif serta memberi kontribusi kepada masyarakat, dan olahraga membantu siswa untuk memahami diri dan masyarakat dimana siswa tinggal.

Penjasorkes memiliki tujuan agar peserta didik memiliki kemampuan sebagai berikut berdasar BSNP (2006, p. 2):

(a) mengembangkan keterampilan pengelolaan diri dalam upaya pengembangan dan pemeliharaan kebugaran jasmani serta pola hidup sehat melalui berbagai aktivitas jasmani dan olahraga yang terpilih, (b) meningkatkan pertumbuhan fisik dan pengembangan psikis yang lebih baik, (c) meningkatkan kemampuan dan keterampilan gerak dasar, (d) meletakan landasan karakter moral yang kuat melalui internalisasi nilai-nilai yang terkandung di dalam pendidikan jasmani, olahraga, dan kesehatan, (e) mengembangkan sikap positif, jujur, disiplin, bertanggung jawab, kerjasama, percaya diri, dan demo- 
kratis, (f) mengembangkan keterampilan untuk menjaga keselamatan diri sendiri, orang lain, dan lingkungan, dan (g) memahami konsep aktivitas jasmani dan olahraga di lingkungan yang bersih sebagai informasi untuk mencapai pertumbuhan fisik yang sempurna, pola hidup sehat dan kebugaran, keterampilan, serta memiliki sifat yang positif.

Penjas sebagai integral dari pendidikan didefinisikan dengan pendapat yang berbedabeda. Physical Education Association of the United Kingdom (PEAUK) menyatakan penjas sebagai kegiatan-kegiatan fisik yang terarah dan studi yang terkait, biasanya dilakukan dalam konteks pendidikan yang mengembangkan kompetensi fisik, membantu mempromosikan pembangunan fisik, dan memungkinkan peserta didik untuk mengetahui tentang dan nilai manfaat partisipasi (Capel \& Piotrowski, 2001, p. 10). Pada dasarnya, penjas adalah penanaman secara formal pengetahuan dan nilai-nilai aktivitas fisik. Definisi lebih luas dikemukakan oleh Chandler, Cronin dan Vamplew (2007, p. 166) bahwa penjas mencakup intruksi dalam pengembangan dan perawatan tubuh, dari latihan callisthersthenic sederhana untuk melatih kebersihan, senam, dan kinerja serta menejemen permainan. Secara historis, telah difokuskan pada diet, olahraga dan kebersihan, serta pengembangan musculo-sketal dan psiko-sosial. Beberapa subdisiplin ilmunya adalah biomikanika, fisiologi olahraga, sosiologi olahraga, sejarah, filsafat, dan psikologi. Pendapat lain dikemukakan oleh Rosidi (2012, p. 23) pendidikan jasmani adalah proses pendidikan yang memanfaatkan aktivitas yang direncanakan secara sistematis bertujuan untuk mengembangkan dan meningkatkan individu secara organik, neuromuskuler, perseptual, kognitif, dan emosional, dan kerangka sistem pendidikan nasional.

Tujuan pendidikan jasmani adalah untuk membantu anak agar tubuh dan berkembang secara wajar dengan tujuan pendidikan nasional, yaitu menjadi manusia seutuhnya (Rosidi, 2012, p.24). Pencapaian tujuan berpangkal pada perencanaan pengalaman gerak yang sesuai dengan karakteristik anak. Jadi, pendidikan jasmani diartikan sebagai proses pendidikan melalui aktivitas jasmani atau olahraga. Inti pengertian ini adalah mendidik anak. Beberapa pendapat tersebut dapat disimpulkan bahwa Penjas merupakan bagian integral dari pendidikan yang pada pelaksanaannya dengan aktivitas fisik dan bertujuan untuk meningkatkan fisik dan psikis.

Kebugaran jasmani merupakan sebuah tuntutan dalam hidup agar lebih sehat dan mampu beraktifitas secara produktif. Tuntutan tersebut terlihat dari program pendidikan jasmani di sekolah dasar, yaitu pembinaan gaya hidup aktif tidak hanya selama seseorang duduk di bangku sekolah namun berlanjut hingga ke masa berikutnya di sepanjang hayat (Lutan, 2002, p. 2).

Dengan memiliki kebugaran jasmani yang baik orang akan mampu melakukan aktivitas sehari-hari dengan waktu lebih lama dibanding orang dengan kebugaran jasmani yang rendah (Suharjana, 2013, p. 2). Setiap orang membutuhkan kebugaran jasmani yang baik agar dapat melaksanakan pekerjaannya dengan efektif dan efisien tanpa mengalami kelelahan yang berarti.

\section{Pembelajaran Mata Pelajaran Penjas, Olahraga, dan Kesehatan}

\section{Karakteristik dan Tujuan Mata Pelajaran}

Rukmana (2008) menyatakan bahwa selaras dengan upaya untuk mencapai tujuan pendidikan maka dalam pendidikan jasmani bukan saja dikembangkan dan dibangkitkan potensi individu tetapi juga ada unsur pendidikan yang dikembangkan meliputi aspek kemampuan fisik, intelektual, emosional, sosial dan moral spiritual yang berorentasi kepada life skill. Sasaran pendidikan jasmani adalah peningkatan kebugaran jasmani dan keterampilan gerak dasar yang kaya dengan koordinasi otot-otot saraf yang halus yang akan bermanfaat bagi kelangsungan hidup sehari-hari dan menjadi pondasi yang kuat untuk suatu cabang olahraga. Lutan (Rukmana, 2008) menyatakan bahwa pendidikan jasmani adalah bagian integral dari pendidikan melalui aktifitas jasmani yang bertujuan untuk meningkatkan individu secara organik, neuromuscular, intelektual, dan emosional".

Penjasorkes merupakan bagian integral dari pendidikan secara keseluruhan, bertujuan untuk mengembangkan aspek kebugaran jasmani, keterampila gerak, keterampilan berfikir kritis, keterampilan sosial, penalaran, stabilitas emosional, tindakan moral, aspek pola hidup sehat dan pengenalan lingkungan bersih melalui aktifitas jasmani, olahraga dan kesehatan terpilih yang direncanakan secara sistimatis dalam rangka mencapai tujuan pendidikan nasional (BSNP, 2006, p. 1). Mata pelajaran ini merupakan media untuk mendorong pertumbuhan fisik, perkem- 
bangan psikis, keterampilan motorik, pengetahuan, penalaran, penghayatan nilai-nilai (sikapmental-emosional-sportivitas-spiritual-sosial) serta pembiasaan pola hidup sehat yang bemuara untuk merangsang pertumbuhan dan perkembangan kualitas fisik dan psikis yang seimbang.

Peranan Penjasorkes di sekolah sangat penting, yaitu memberikan kesempatan kepada peserta didik untuk mendapatkan pengalaman secara langsung dalam berbagai kesempatan melalui aktivitas jasmani, olahraga, dan kesehatan yang terpilih dan dilakukan secara sitematis. Pemberian materi praktik terdiri atas permainan dan olahraga, aktifitas air, pendidikan luar kelas dapat memberikan kesempatan kepada peserta didik untuk beraktivitas jasmani/gerak yang terarah yang mampu memberikan kesempatan pada peserta didik untuk lebih mengenal dunia dan dirinya sendiri sehingga peserta didik secara alami senantiasa mendapatkan manfaat berupa kesehatan dan kebugaran tubuh. Selain itu pemberian materi kesehatan yang di dalamnya terdiri atas materi pola dan budaya hidup sehat serta penerapannya dalam kehidupan sehari-hari mampu memberikan dasar pemahaman peserta didik akan pentingnya memiliki kebiasaan tentang hidup sehat.

Tujuan penjas di SD menurut Lee, Thomas, \& Thomas (2000, p. viii) ada dua yaitu: (1) membuat gerakan dan olahraga menjadi lebih efiensi shingga siswa dapat mengaplikasikan dalam aktivitas olahraga untuk sepesialisasi, dan (2) membangun dan atau memelihara kesehatan fisik. Pendapat senada dikemukakan oleh Capel dan Piotrowski (2001, p. 10) menyatakan bahwa penjas di sekolah bertujuan untuk mengembangkan kontrol, koordinasi dan penguasaan tubuh. Hal ini berkaitan dengan cara belajar melalui tindakan, sensasi dan observasi.

Dari tujuan-tujuan yang dikembangkan di atas dan juga jika dilihat dari tujuan yang ada di BNSP (2006, p. 2) maka tujuan mata pelajaran penjasorkes adalah agar peserta didik memiliki kemampuan sebagi berikut: (1) mengembangkan keterampilan pengelolaan diri dalam upaya pengembangan dan pemeliharaan kebugaran jasmani serta pola hidup sehat melalui berbagai aktivitas jasmani dan olahraga terpilih; (2) meningkatkan pertumbuhan fisik dan pengembangan psikis yang lebih baik; (3) meningkatkan kemampuan dan keterapilan gerak dasar; (4) meletakkan landasan karakter moral yang kuat melalui internalisasi nilai-nilai yang terkandung dalam penjas, olahraga, dan kesehatan; (5) mengembangkan sikap sportif, jujur, disiplin, bertanggunng jawab, kerja sama, percaya diri dan demokratis; (6) mengembangkan keterampilan untuk menjaga keslamatan diri sendiri, orang lain, dan lingkungan.

Memahami konsep aktivitas jasmani dan olahraga di lingkungan yang bersih sebagai informasi untuk mencapai pertumbuhan fisik yang sepurna, pola hidup sehat dan kebugaran, terampil, serta memiliki sikap positif.

\section{Ruang Lingkup Materi}

Ruang lingkup materi penjas meliputi aspek-aspek sebagai berikut Depdiknas (2003, p. 10): (1) permainan dan olahraga meliputi: olahraga tradisional, permainan, eksplorasi gerak, meliputi: olahraga tradisional, permainan, eksplorasi gerak, keterampilan lokomotor non lokomotor dan manipulatif, atletik, kasti, roundrs, kippres, softball, baseball, bola tangan, sepak bola, bola voli, bola basket, tenis meja, tenis, bulutangkis, dan beladiri, serta aktivitas lainya; (2) Aktivitas pengembangan meliputi: mekanika sikap tubuh, komponen kebugaran jasmani, bentuk postur tubuh dan aktivitas lainya. (3) Aktivitas senam meliputi: senam lantai, ketangkasan tanpa alat, ketangkasan dengan alat, dan aktivitas lainya. (4) Aktivitas ritmik meliputi: gerak bebas berirama, senam pagi indonesia, SKJ, senam aerobik dan aktivitas lainya. (5) Aktivitas air meliputi: permainan di air, keselamatan air, keterampilan gerak di air, dan renang serta aktivitas lainya.

Pendidikan luar kelas, meliputi: piknik/ karya wisata, berkemah, menjelajah, menaiki gunung dan aktivitas lainya.

\section{Permainan Bola Tangan dalam Pembelajaran Penjas}

Sesuai dengan kurikulum yang dilaksanakan sekarang ini, bahwa di sekolah dasar (SD) juga diberikan permainan bola tangan tetapi dalam Kompetensi Dasar memahami konsep variasi dan kombinasi pola gerak dasar dalam berbagai permainan dan atau olahraga tradisonal bola besar. Permainan bola tangan yang tercantum di dalam kurikulum yaitu memahami konsep dasar dalam berbagai permainan untuk dilaksanakan di SD. Permainan bola tangan yang umum dimainkan oleh orang dewasa terlihat mengalami kesulitan jika diterapakan di sekolah-sekolah. Dengan adanya beberapa kesulitan yang dialami sesuai kondisinya, maka penelitian mempermudah peserta didik memahami dan semudah mungkin dapat dilaksanakan oleh peserta didik. Agar permainan bola tangan 
Jurnal Keolahragaan 4 (1), April 2016 - 65

Muhamad Abdurrochim, Hari Amirullah Rachman

dapat dilaksanakan di Sekolah dasar, maka kemudian diwujudkan dalam bentuk pengembangan permainan bola tangan.

Permainan bola tangan yang dikembangkan ini, pada dasarnya merupakan permainan bola tangan seperti yang dimainkan oleh orang dewasa pada umumnya. Oleh karena itu, nantinya istilah permainan bola tangan ditambahkan istilah mini, hal ini dimaksudkan untuk menggambarkan permainan yang lebih sederhana. Pemberian Istilah mini dikaitkan dengan ukuran lapangan yang lebih kecil, peraturan yang tidak terlalu rumit, perelengkapan yang lebih sederhana, dan perwasitan yang lebih sederhana. Ini dimaksudkan agar lebih mudah dimengerti oleh anak-anak, sehingga dapat dilaksanakan dengan baik. Selain permainan bola tangan ini merupakan permainan bola tangan yang sifatnya lebih sederhana, permainan bola tangan yang dikembangkan ini masih memberikan toleransi tertentu atau kemungkinan dimainkan dengan tangan.

Menurut Rahman \& Susanto (2007, p. 17) Bola tangan adalah olahraga dinamis yang membuat badan kita menjadi terlatih, bersemangat dan berakal, dan melatih pemain untuk bekerja sama sebagai sebuah tim. Menurut Mahendra (2000, p. 10) keterampilan bermain bola tangan selalu di bangun tersebut keterampilan dasar lokomotor, nonlokomotor, dan manipulatif".

\section{Lokomotor}

Lokomotor atau sering disebut traveling, diartikan sebagi gerak berpindah tempat, seperti jalan, lari, dan melompat. Ketiga keterampilan ini dianggap sebagai keterampilan paling dasar dari lokomotor, karena merupakan keterampilan yang berkembang bersama perkembangan dan lebih bersifat fungsional. banyak juga keterampilan lokomotor yang harus dipelajari secara khusus meskipun tidak lama, karena tidak bersifat fungsional. Contoh dari keterampilan tersebut adalah skipping, leaping, galloping, dan sliding.

\section{Nonlokomotor}

Keterampilan nonlokomotor adalah gerak yang tidak berpindah tempat. Contoh, gerakan seperti melenting, memilin, meliuk, membengkok. Keterampilan ini biasanya melibatkan kelompok otot besar dari tubuh. Untuk bisa melenting atau meliuk, tubuh mengkontraksikan otototot bagian yang sesuai dengan arah gerakan (protagonis) dan melemaskan otot yang berlawanan (antagonis).
Manipulatif

Kegiatan yang digunakan untuk mengontrol benda lain di luar tubuh sendiri disebut manipulatif. Peserta didik yang sudah terampil dalam keterampilan ini hampir tidak memikirkan bahwa sedang melakukan suatu tugas yang berat namun pada awalnya bahkan untuk menangkap bola saja peserta didik sering kesulitan.

\section{Karakteristik Anak Sekolah Dasar Usia 10 - 12 Tahun}

Menurut Desmita (2012, p. 35) usia ratarata anak Indonesia saat masuk sekolah dasar adalah 6 tahun dan selesai pada usia 12 tahun. Kalau mengacu pada pembagian tahap perkembangan anak, berarti anak usia sekolah berada dalam dua masa perkembangan, yaitu masa kanak-kanak tengah (6-9 tahun), dan masa kanakkanak akhir (10-12 tahun). Yusuf LN (2009, p. 184) berpendapat bahwa perkembangan fisik yang normal merupakan salah satu faktor penentu kelancaran proses belajar, baik dalam bidang pengetahuan maupun keterampilan. Oleh karena itu, perkembangan motorik sangat menunjang keberhasilan belajar peserta didik. Pada masa usia sekolah dasar kematangan perkembangan motorik ini pada umumnya dicapai, karena itu anak sudah siap menerima pelajaran perkembangan.

Anak-anak usia sekolah ini memiliki karakteristik yang berada dengan anak-anak yang usianya lebih muda. anak senang bermain, senang bergerak, senang bekerja dalam kelompok, dan senang merasakan atau melakukan sesuatu secara berlangsung. Oleh sebab itu, guru hendaknya mengembangkan pembelajaran yang mengandung unsur permainan, mengusahakan siswa berpindah atau bergerak, bekerja atau belajar dalam kelompok, serta memberikan kesempatan untuk terlibat langsung dalam pembelajaran.

Sedangkan menurut Yusuf LN (2009, p. 178-184), fase perkembangan anak usia 10-12 tahun sebagai berikut: Pertama, Perkembangan intelektual, dengan ciri-ciri (1) sudah dapat mereaksi rangsangan intelektual, (2) melaksanakan tugas-tugas belajar yang menuntut kemampuan intelektualnya, (3) berpikir konkret dan rasional, (4) mampu memecahkan masalah yang sederhana. Kedua, Perkembangan bahasa, yang memiliki ciri-ciri (1) perbendaharaan kata meningkat pesat, (2) mendengar dan membaca cerita yang bersifat kritis, (3) lebih banyak menanyakan sebab akibat, (4) mampu menyatakan 
gagasan atau pendapat, (5) menyatakan isi hatinya kepada orang lain. Ketiga, Perkembangan sosial, dengan ciri-ciri (1) ruang gerak hubungan sosial bertambah luas, (2) lebih kooperatif dan sosiosentris, (3) mampu menyesuaikan diri dengan kelompok, (4) tidak senang jika tidak diterima dalam kelompoknya. Keempat, Perkembangan emosi, ciri-cirinya (1) mampu mengontrol dan mengendalikan emosi, (2) emosi yang positif akan mempengaruhi untuk lebih berkonsentrasi dalam belajar, (3) emosi negatif akan menghambat kegiatan belajar. Kelima, Perkembangan moral dengan ciri-ciri (1) mengikuti tuntutan dari orang tua atau lingkungan sosial, (2) mampu memahami suatu peraturan yang berlaku, dan (3) mampu mengasosiasikan benar salah. Keenam, Perkembangan penghayatan keagamaan, yaitu (1) sifat keagamaan bersifat reseptif disertai dengan pengertian, (2) pandangan ketuhanan diperoleh secara rasional, dan (3) penghayatan rohaniah semakin mendalam. Ketujuh, Perkembangan motorik, yaitu: (1) perkembangan motorik sudah terkoordinasi, (2) gerakan selaras dengan kebutuhan, (3) terjadi kelebihan gerak, dan (4) siap menerima pelajaran keterampilan.

Dalam upaya mencapai setiap tugas perkembangan tersebut, guru dituntut untuk memberikan bantuan berupa: (1) menciptakan lingkungan teman sebaya yang mengajarkan keterampilan fisik, (2) melaksanakan pembelajaran yang memberikan kesempatan pada siswa untuk belajar bergaul dan bekerja dengan teman sebaya, sehingga kepribadian sosialnya berkembang. Mengembangkan kegiatan pembelajaran yang memberikan pengalaman yang kongkret atau lang sung dalam membangun konsep.

\section{Bermain Pada Anak Usia 10 - 12 Tahun}

Setelah mengetahui batasan-batasan bermain seperti yang telah di kemukakan tersebut, beberapa ahli mengelompokkan permainan menjadi beberapa kelompok. Bahagia (2010, p. 115-116) mengelompokkan bermain: (a) permainan net (net games/rallying), (b) Permainan Invasi (Invation Games/Pasing Intercepting), (c) Permainan Sentuh (Tag Games/Staying In Versus Making Out).

\section{Permainan Net (Net Games/Rallying)}

Berbagai permainan yang menggunakan net sebagai pembatas lapangan, memainkannya dengan rally dan mengusahakan alat atau bola yang digunakan dalam permainan tidak jatuh di dalam area lapangan sendiri atau tidak keluar lapangan setelah sentuhan dari seseorang pemain suatu regu. Contoh: Voli, bulutangkis, tenis meja, tenis lapangan.

\section{Permainan Invasi (Invation Games/Pasing Intercepting)}

Berbagai permainan yang bertujuan untuk melakukan penyerangan kedaerah/lapangan dengan tujuan untuk membuat sekor/goal. Jalannya permainan dilakukan dengan jalan melakukan operan kepada teman seregu dan melakukan hadangan terhadap usaha operan-operan tersebut. Contoh: Sepak bola (soccer like games), bola tangan (Handball like games), hoki, basket, korfball, Frisbie, polo air, rughby.

\section{Permainan Sentuh (Tag Games/Staying In Versus Making Out).}

Berbagai permainan yang menggunakan sentuhan sebagai media untuk mematikan lawan. Sentuhan yang dimaksud bisa berupa sentuhan pada seseorang anggota pemain lawan yang sedang main atau sentuhan terhadap sasaran berupa base. Contoh: Sof ball, Baseball, permainan tradisional galah asin, bebentengan.

\section{Hakikat, Klasifikasi dan Manfaat Permainan}

Permainan dapat diklasifikasi menjadi beberapa bentuk. Bahagia \& Suherman (2000, pp. 22-30) mengklarifikasi permainan menjadi 5 bentuk yaitu: (a) permainan sentuh (tag game), (b) permainan target (target game), (c) permainan net dan dinding (net and wall game), (d) permainan serangan (invasion game), dan (e) permainan lapangan (fielding game). Adapun penjelasannya adalah sebagai berikut:

\section{Permainan Sentuh (Tag Game)}

Permainan sentuh merupakan sebuah bentuk permainan strategi yang sederhana namun sangat berguna untuk mengembangkan dasardasar setrategi. Tujuan permainan ini adalah untuk bergerak, mengubah arah, dan mengecoh, yang bertujuan agar dapat (1) menyentuh lawan atau menyebabkan lawan kehilangan kendali terhadap objeknya, (2) menghindari sentuhan lawan terhadap objek yang sedang dikendalikan. Contoh, kucing-kucingan, galah asin. Cara yang dapat dikembangkan dalam permainan sentuhan adalah sebagai berikut, (a) Berdiri seimbang dan siap bergerak ke berbagai arah, (b) mengunakan variasi pura-pura pada saat menyentuh dan purapura menyentuh, (c) merubah arah dan kecepatan dalam gerak mengecoh, (d) menyadari apa yang terjadi di sebelah dan di belakang. 


\section{Permainan Target (Target Game)}

Permainan target merupakan sebuah bentuk permainan akurasi penyampaian objek pada sasaran atau target. Tujuan permainan ini adalah akurasi penyampaian obyek pada sasaran. Skill yang dilibatkan dalam permainan ini pada umumnya dilakukan secara pasif atau cenderung bersifat close skill. Contoh dari bentuk permainan target ini adalah, bowling, golf, panahan, memukul, menendang, dan melempar pada target. Strategi dasar pada permainan target adalah membuat keputusan apakah memilih kesempurnaan atau memilih cara atau tingkat yang aman. Strategi dasar ini dapat diperinci sebagai berikut (a) behenti sesaat, relaks dan tumbuhkan rasa percaya diri, (b) jangan terburu-buru, tentukan kapan akan memulainya, (c) menilai kemampuan diri dan situasi yang ada, kemudian memutuskan apakah memilih dengan sempurna atau memilih amannya. (d) berkonsentrasi dan konsen sebisanya.

\section{Permainan Net dan Dinding (Net and Wall Game)}

Permainan net dan dinding merupakan sebuah permainan yang melibatkan kemampuan bergerak dan mengendalikan objek agar susah dimiliki lawan ke dinding. Pemain pada permainan ini harus mampu mengendalikan daerahnya. Pemain bergerak di dalam daerahnya untuk menempatkan diri pada posisi yang strategis yang dapat menangkap kembalian pukulan atau lemparan lawan. Contoh bentuk permainan ini adalah tenis, badminton, bola tangan, dan tenis meja. Beberapa strategi yang digunakan dalam permainan net dan dinding adalah: (1) mengirimkan objek ke dinding atau mengirimkan objek melewati net menuju daerah yang kosong, (2) memulai dan kembali ke posisi strategis semula setiap selesai memulai. (3) memainkan secara bervariasi sehingga lawan tidak mudah membaca gerakan, (4) membagi daerah sama teman satu tim, (5) komunikasi sama teman tim sehingga dapat membantu satu sama lain.

\section{Permainan Serangan (Invansion Games)}

Permainan ini lebih berfokus perhatiannya pada pengendalian objek pada daerah tertentu. Permainan ini meliputi permainan yang sederhana seperti permainan merebut bola. Bentuk permainan ini biasa dianggap lebih komplek. Pada permainan ini, satu tim berusaha mengendalikan bola bergerak menuju sasaran, (misalnya smes dalam permainan bola tangan). Berbagai strategi dasar permainan serangan adalah sebagai berikut: (1) menciptakan agar pertahanan tetap siap, (2) menjaga wilayah untuk bertahan, (3) menjaga dan menghambat gerak lawan, (4) memindahkan objek pada daerah yang memungkinkan, dan (5) berkomunikasi bersama teman secara efektif.

\section{Permainan Lapangan (fielding games)}

Permainan ini biasanya sebuah objek dikirimkan pada sebuah tempat atau daerah tertentu dan pengirim berusaha lari ke tempat tertentu dan bahkan mungkin terus lari sampai kembali lagi ke tempat semua sebelum pemain penangkap bola dan mengirimkannya lagi ketempat semula. Permainan ini dapat disederhanakan dengan cara mengurangi skill yang diperlukannya, misalnya dilakukan dengan skill mengoper dan menyemes atau dipadukan dengan bermain sentuhan.

\section{METODE}

\section{Model Pengembangan}

Penelitian ini menggunakan metode penelitian dan pengembangan, bertujuan untuk mengembangkan model permainan bola tangan sebagai pembelajaran penjasorkes bagi anak SD kelas atas. Kemudian dalam melakukan pengembangan, pada tahap pemilihan bentuk aktivitas yang dikembangkan juga melihat pada tahap-tahap perkembangan serta karakteristik anak sehingga model yang dihasilkan cocok atau sesuai bagi anak dengan tahapan perkembangan anak.

\section{Prosedur Pengembangan}

Penelitian pengembangan yang akan dilakukan dalam penelitian ini adalah dengan memodifikasi model pengembangan Borg \& Gall (1983, p.775) menjadi enam langkah yaitu: (1) studi pendahuluan, (2) perencanaan penelitian, (3) pengembangan produk awal, (4) uji lapangan terbatas, (5) revisi hasil uji coba lapangan terbatas, (6) uji coba lapangan luas. Secara umum, penelitian pengembangan ini dilakukan dengan mengikuti langkah-langkah yang telah dibuat dalam model pengembangan yang dikelompokkan ke dalam empat tahapan pengembangan, di mana tahap dalam pengembangan yang dilakukan tersebut meliputi; (a) studi pendahuluan, (b) pengembangan, (c) uji lapangan, (d) diseminasi (pengenalan produk). 


\section{Tempat dan Waktu Pengembangan}

Penelitian pengembangan ini dilaksanakan pada SD 1 Petir Bantul, SD N Kembangsari Piyungan, SD N Petir II Piyungan, SD N Petri 1 dan MI Sananul Ula Piyungan. Dilakukan dari bulan Desember 2013 sampai dengan bulan Maret 2014, sehingga dapat dikatakan bahwa lama penelitian dari proses awal sampai proses akhir adalah 4 bulan

\section{Desain dan Subjek Uji Coba}

Desain Uji Coba

Uji coba produk dilakukan untuk mendapat data yang akan digunakan untuk mengetahui kelemahan-kelemahan produk yang dikembangkan sebagai dasar untuk melakukan revisi produk yang berupa model permainan bola tangan untuk anak kelas atas. Uji coba produk dalam penelitian ini dilakukan dalam dua tahap yaitu: (a) uji coba skala kecil, dan (b) uji coba skala luas.

\section{Subjek Uji Coba}

Subjek coba dalam penelitian pengembangan yang dilakukan ini sebanyak 121 orang yaitu; (a) 22 uji lapangan terbatas, (b) 98 orang anak uji lapangan lebih luas. Subjek uji coba merupakan sasaran pemakai yaitu siswa SD kelas atas

\section{Jenis Data}

Data yang dikumpulan dari penelitian ini adalah berupa data kualitatif. Data kualitiatif diperoleh dari ahli, dari guru Penjasorkes dan Siswa. Sedangkan untuk uji di lapangan dengan skala kecil dan sekala luas data dihasilkan dari hasil observasi yang diberikan kepada para ahli serta guru Penjasorkes saat mengobservasi pelaksanaan uji coba yang telah didokumentasi dalam wujud VCD. Data dari siswa didapatkan dari hasil kuesioner setelah siswa mengikuti/ menjadi subjek uji coba dalam skala luas.

\section{Instrumen Pengumpulan Data}

Instrumen yang digunakan untuk mengumpulkan data berupa instrumen penilaian untuk menilai produk yang telah dikembangkan baik dari aspek kesesuaian, aspek isi, aspek kemudahan, dan aspek rangsangan terhadap gerak siswa. Instrumen yang dikembangkan dan digunakan dalam penelitian ini meliputi: (a) kuesioner untuk ahli dan guru, dan (b) lembar evaluasi untuk siswa untuk mengevaluasi proses pembelajaran dengan modul pembelajaran yang dikembangkan.

\section{Tenkik Analisis Data}

Teknik analisis data yang digunakan dalam penelitian ini adalah analisis data deskriptif. Model yang disusun ini dianggap layak untuk diuji cobakan dalam sekala kecil apabila dihitung skor yang diraih mencapai standar minimal kelayakan. Sekor tersebut didapat dari pengisian angket yang telah diberikan, dalam angket terdapat empat skala penilaian yaitu 1, 2, 3, dan 4. Kemudian skala tersebut diterjemahkan ke dalam sistem pensekoran seperti pada Tabel 5 .

Tabel 5. Tabel Skor Angket

\begin{tabular}{cccc}
\hline No & $\begin{array}{c}\text { Sekala Dala } \\
\text { Angket }\end{array}$ & $\begin{array}{c}\text { Skor Hasil } \\
\text { Konversi }\end{array}$ & $\begin{array}{c}\text { Sekor Maksimal } \\
\text { (3 Pertanyaan) }\end{array}$ \\
\hline 1 & 1 & 5 & 15 \\
2 & 2 & 4 & 12 \\
3 & 3 & 2 & 6 \\
4 & 4 & 1 & 3 \\
\hline
\end{tabular}

\section{HASIL DAN PENGEMBANGAN}

\section{Validasi Ahli}

Tabel. Data Pengisian Kuisioner Ahli

\begin{tabular}{cccc}
\hline \multirow{2}{*}{$\begin{array}{c}\text { Aspek yang } \\
\text { dinilai }\end{array}$} & \multicolumn{2}{c}{$\begin{array}{c}\text { Sekor Penilaian } \\
\text { dari Ahli }\end{array}$} & \multirow{2}{*}{$\%$} \\
\cline { 2 - 3 } & $\mathbf{A 1}$ & $\mathbf{A 2}$ & \\
\hline 1. & 1 & 1 & $100 \%$ \\
2. & 1 & 1 & $100 \%$ \\
3. & 1 & 1 & $100 \%$ \\
4. & 1 & 1 & $100 \%$ \\
5. & 1 & 1 & $100 \%$ \\
6 & 1 & 1 & $100 \%$ \\
7 & 1 & 1 & $100 \%$ \\
8 & 1 & 1 & $100 \%$ \\
9 & 1 & 1 & $100 \%$ \\
10 & 1 & 1 & $100 \%$ \\
11 & 1 & 1 & $100 \%$ \\
12 & 1 & 1 & $100 \%$ \\
13 & 1 & 1 & $100 \%$ \\
14 & 1 & 1 & $100 \%$ \\
15 & 1 & 1 & $100 \%$ \\
Jumlah skor & 15 & 15 & \\
Rata-rata & 1 & 1 & $100 \%$ \\
\hline
\end{tabular}

Keterangan:

A1: Ahli, A2: Ahli,

Dari hasil pengisian kuesioner yang dilakukan oleh masing-masing ahli maka didapatkan rata-rata nilai kesesuaian peraturan permainan bola tangan sebesar $100 \%$ yang masuk ke dalam kategori sesuai. Selain penilain yang dilakukan oleh ahli, masukan yang berupa saran dan komentar pada produk peraturan permainan bola 
tangan juga diberikan untuk perbaikan terhadap model tersebut. Adapun masukan-masukan tersebut adalah: Masukan ahli 1, yaitu (1) semua istilah asing diubah ke dalam bahasa Indonesia supaya mudah untuk dipahami. Contoh: handball (bola tangan), circle (lingkaran) dan lainlain, (2) untuk keperluan peneliti mengembangkan aturan yang lebih sederhana agar dipahami oleh guru, (3) buat tabel perbedaan peraturan bola tangan yang sesungguhnya dengan yang dimodifikasi, dan (4) gunakan rules of the game bola tangan tetapi disesuaikan untuk anak usia siswa SD kelas atas.

Masukan ahli 2, yaitu: (1) banyak peraturan yang dikurangi, (2) ukuran gawang diubah tinggi gawang 2 meter dan lebar gawang 3 meter, (3) perlu diperhatikan penggunaan bola demi keselamatan siswa, (4) ukuran lapangan dari lebar 5 meter, panjang 10 meter, dirubah menjadi panjang lapangan 20 meter dan lebar 10 meter.

\section{Data Uji Coba Skala Kecil}

Tabel 8. Data Hasil Pengisian Kuesioner Ahli dan Guru Setelah Uji coba Skala Kecil

\begin{tabular}{ccccc}
\hline & \multicolumn{4}{c}{ Sekor Penilaian } \\
Aspek yang dinilai & \multicolumn{2}{c}{ dari Ahli dan Guru } & \multirow{2}{*}{$\%$} \\
\cline { 2 - 4 } & A1 & A2 & G & \\
\hline 1. & 1 & 1 & 1 & $100 \%$ \\
2. & 1 & 1 & 1 & $100 \%$ \\
3. & 1 & 1 & 1 & $100 \%$ \\
4. & 1 & 1 & 1 & $100 \%$ \\
5. & 1 & 1 & 1 & $100 \%$ \\
6 & 1 & 1 & 1 & $100 \%$ \\
7 & 1 & 1 & 1 & $100 \%$ \\
8 & 1 & 1 & 1 & $100 \%$ \\
9 & 1 & 1 & 1 & $100 \%$ \\
10 & 1 & 1 & 1 & $100 \%$ \\
11 & 1 & 1 & 1 & $100 \%$ \\
12 & 1 & 1 & 1 & $100 \%$ \\
13 & 1 & 1 & 1 & $100 \%$ \\
14 & 1 & 1 & 1 & $100 \%$ \\
15 & 1 & 1 & 1 & $100 \%$ \\
\hline
\end{tabular}

Keterangan:

A1: Ahli, A2:Ahli, G: Guru

Dari hasil pengisian kuesioner yang dilakukan oleh masing-masing ahli setelah menyaksikan pelaksanaan uji coba skala kecil, dengan melihat video hasil rekaman pelaksanaan uji coba skala kecil, didapatkan rata-rata nilai kesesuaian peraturan permainan bola tangan sebesar $100 \%$ yang masuk ke dalam kategori sesuai. Selain penilain yang dilakukan oleh ahli, masukan yang berupa saran dan komentar pada produk peraturan permainan bola tangan juga diberikan untuk perbaikan terhadap model hasil uji coba skala kecil. Adapun masukan-masukan tersebut adalah: Masukan ahli 1, yaitu: Jika siswa yang menjadi kipper tidak mau mengenakan helm, guru tidak boleh memaksa siswa mengenakan helm dan sebelum melakukan pertandingan, guru harus menerangkan secara jelas kepada setiap siswa mengenai peraturan peraturan permainan bola tangan.

Masukan ahli 2, yaitu (1) berdasarkan hasil rekaman ditemukan beberapa pelanggaran yang tidak ditindak tegas oleh wasit, (2) wasit harus benar-benar menguasai peraturan bola tangan secara baik, dan (3) dalam pelaksanaan permainan, banyak siswa yang tidak mempraktikkan teknik dasar dribble secara baik.

Masukan dari guru penjasorkes SD, yaitu (1) perlu adanya aturan mengenai lokasi penonton pertandingan, (2) perlu adanya pemain yang merangkap sebagai official tim, dan bertugas mengatur strategi dan pergantian antar pemain.

Tanggapan dari siswa dilakukan dengan cara memberikan lembaran kuesioner yang berisi sepuluh pertanyaan yang mencakup aspek kemudahan, alat dan kesenangan permainan yang dilakukan. Siswa yang diminta mengisi lembar kuesioner sejumlah 23 siswa. Adapun tanggapan dari anak dapat dilihat pada Tabel 8.

Tabel 9. Data Hasil Observasi dari Siswa

\begin{tabular}{|c|c|c|c|c|}
\hline \multirow{2}{*}{ Pertanyaan } & \multicolumn{2}{|c|}{$\begin{array}{c}\text { Jumlah } \\
\text { Jawaban Siswa }\end{array}$} & \multicolumn{2}{|c|}{ Persentase (\%) } \\
\hline & Ya & Tdk & Ya & Tdk \\
\hline 1 & 23 & 0 & $100 \%$ & $0 \%$ \\
\hline 2 & 23 & 0 & $100 \%$ & $0 \%$ \\
\hline 3 & 22 & 1 & $95.65 \%$ & $4.35 \%$ \\
\hline 4 & 19 & 4 & $82.61 \%$ & $17.39 \%$ \\
\hline 5 & 2 & 21 & $8.70 \%$ & $91.30 \%$ \\
\hline 6 & 22 & 1 & $95.65 \%$ & $4.35 \%$ \\
\hline 7 & 23 & 0 & $100 \%$ & $0 \%$ \\
\hline 8 & 23 & 0 & $100 \%$ & $0 \%$ \\
\hline 9 & 22 & 1 & $95.65 \%$ & $4.35 \%$ \\
\hline 10 & 5 & 18 & $21.74 \%$ & $78.26 \%$ \\
\hline Jumlah & 184 & 46 & & \\
\hline Rata-rata & 18.4 & 4.6 & $80 \%$ & $20 \%$ \\
\hline
\end{tabular}

Dari data Tabel 9 terlihat bahwa produk yang diberikan menurut tanggapan siswa 100\% dapat dilakukan, mudah, menyenangkan dan dapat membuat anak senang bergerak, 95,65\% anak dapat memahami peraturan, $82.61 \%$ anak taat pada peraturan, $8,70 \%$ mengalami kesulitan, $95,65 \%$ suka dengan alat yang digunakan untuk bermain, $95.65 \%$ dapat melakukan kerjasama, dan $21,74 \%$ merasa takut melakukan permainan yang diajarkan. Melihat tanggapan tersebut maka produk menurut pandangan siswa adalah 
cukup sesuai dengan siswa, namun revisi produk menurut pandangan para ahli dan guru Penjasorkes, tetap harus dilakukan demi meningkatkan kualitas permainan bola tangan yang dikembangkan.

Tabel 11. Data Hasil Pengisian Kuesioner Ahli dan Guru setelah Uji coba Skala Luas

\begin{tabular}{cccccccc}
\hline \multirow{2}{*}{$\begin{array}{c}\text { Aspek yang } \\
\text { dinilai }\end{array}$} & \multicolumn{7}{c}{$\begin{array}{c}\text { Sekor Penilaian } \\
\text { dari Ahli dan Guru }\end{array}$} \\
\cline { 2 - 7 } & AI & A2 & G1 & G2 & G3 & G4 & \\
\hline $\mathbf{1}$ & 1 & 1 & 1 & 1 & 1 & 1 & 100 \\
$\mathbf{2}$ & 1 & 1 & 1 & 1 & 1 & 1 & 100 \\
$\mathbf{3}$ & 1 & 1 & 1 & 1 & 1 & 1 & 100 \\
$\mathbf{4}$ & 1 & 1 & 1 & 1 & 1 & 1 & 100 \\
$\mathbf{5}$ & 1 & 1 & 1 & 1 & 1 & 1 & 100 \\
$\mathbf{6}$ & 1 & 1 & 1 & 1 & 1 & 1 & 100 \\
$\mathbf{7}$ & 1 & 1 & 1 & 1 & 1 & 1 & 100 \\
$\mathbf{8}$ & 1 & 1 & 1 & 1 & 1 & 1 & 100 \\
$\mathbf{9}$ & 1 & 1 & 1 & 1 & 1 & 1 & 100 \\
$\mathbf{1 0}$ & 1 & 1 & 1 & 1 & 1 & 1 & 100 \\
$\mathbf{1 1}$ & 1 & 1 & 1 & 1 & 1 & 1 & 100 \\
$\mathbf{1 2}$ & 1 & 1 & 1 & 1 & 1 & 1 & 100 \\
$\mathbf{1 3}$ & 1 & 1 & 1 & 1 & 1 & 1 & 100 \\
$\mathbf{1 4}$ & 1 & 1 & 1 & 1 & 1 & 1 & 100 \\
$\mathbf{1 5}$ & 1 & 1 & 1 & 1 & 1 & 1 & 100 \\
\hline
\end{tabular}

Keterangan:

AI: Ahli, A2: Ahli, G1: guru, G2: guru, G3: Guru, G4: Guru,

Dari hasil observasi dalam uji coba skala luas dapat dilihat bahwa model yang telah direvisi dari hasil uji coba skala kecil tersebut semakin menunjukkan kesesuaian dengan harapan terhadap kualitas modifikasi model permainan bola tangan yang baik. Hal ini dapat dapat dilihat dari hasil observasi yang menyatakan bahwa permainan sebagai model sesuai dengan Standar Kompetensi dan Kompetensi Dasar $(100 \%)$, ketepatan memilih model permainan bagi siswa (100\%), petunjuk pelaksanan permainan jelas (100\%), kesesuain alat dan fasilitas yang digunakan (100\%), kemudahan model permainan untuk dimainakan siswa (100\%), kesesuaian model permainan dengan karakteristik siswa (100\%), permainan mendorong perkembangan aspek fisik siswa (100\%), permainan mendorong perkembangan aspek kognitif siswa (100\%), permainan mendorong perkembangan aspek fisik siswa (100\%), permainan mendorong perkembangan aspek kognitif siswa (100\%), permainan mendorong aspek aspek psikomotor siswa yang mencakup gerak lokomotor, nonlokomotor dan manipulatif siswa (100\%), permainan mendorong perkembangan aspek afektif siswa (100\%), permainan mendorong kemampuan kompetitif siswa (100\%), model permainan dapat dimainkan oleh siswa dan siswa (100\%), model permainan dapat merangsang siswa untuk aktif bergerak (100\%), model permainan dapat memperkenalkan bola tangan bagi siswa (100\%), model permainan aman dilakukan oleh siswa (100\%).

Selain pada uji coba skala kecil, dalam uji coba skala luas ini peneliti juga melakukan pengambilan data berupa kuesioner kepada siswa yang mengikuti proses permainan bola tangan tersebut. Kuesioner ini disusun untuk mengetahui tanggapan siswa terhadap model yang telah disusun dan telah disampaikan oleh guru mata pelajaran Penjasorkes. Setelah data diambil pada 98 siswa yang menjadi sampel uji coba model skala luas, dapat diproleh data yang dapat dilihat pada Tabel 12 .

Tabel 12. Rekapitulasi Kuesioner yang Diberikan Pada Siswa

\begin{tabular}{ccccc}
\hline \multirow{2}{*}{ Pertanyaan } & \multicolumn{2}{c}{$\begin{array}{c}\text { Jumlah } \\
\text { Jawaban } \\
\text { Siswa }\end{array}$} & \multicolumn{2}{c}{ Persentase (\%) } \\
\cline { 2 - 5 } & Ya & Tidak & Ya & Tidak \\
\hline 1 & 98 & 0 & 100 & 0.00 \\
2 & 89 & 9 & 90.82 & 9.18 \\
3 & 93 & 5 & 94.90 & 5.10 \\
4 & 91 & 7 & 92.86 & 7.14 \\
5 & 17 & 81 & 17.35 & 82.65 \\
6 & 96 & 2 & 97.96 & 2.04 \\
7 & 97 & 1 & 98.98 & 1.02 \\
8 & 98 & 0 & 100 & 0.00 \\
9 & 94 & 4 & 95.92 & 4.08 \\
10 & 14 & 84 & 14.29 & 85.71 \\
Jumlah & 787 & 193 & $803.06 \%$ & $196.94 \%$ \\
Sekor & 78.7 & 19.3 & $80.31 \%$ & $19.69 \%$ \\
Rata-rata & & & & \\
\hline
\end{tabular}

Dari data Tabel 12 terlihat bahwa produk yang diberikan menurut tanggapan siswa $100 \%$ dapat dilakukan dan membuat anak senang bergerak, 90,82\% mudah dilakukan, 94,90\% dapat memahami peraturan dengan baik, $92,86 \%$ siswa taat pada peraturan yang berlaku, $17,35 \%$ siswa mengalami kesulitan, 97,96\% siswa merasa suka dengan peralatan yang digunakan, 98,98\% permainan menyenangkan, 95,92\% dapat melakukan kerjasama, dan 14,29\% merasa takut melakukan permainan yang diajarkan. Melihat tanggapan tersebut maka produk menurut pandangan siswa adalah cukup sesuai dengan siswa, namun revisi produk menurut pandangan para ahli dan guru Penjasorkes, tetap harus dilakukan demi meningkatkan kualitas permainan bola tangan yang dikembangkan. 


\section{Produk Akhir}

Berikut ini adalah produk akhir model yang merupakan revisi dari beberapa tahapan sebelumnya dan terutama revisi setelah uji coba skala luas.

Aturan Bola Tangan

\section{Garis Besar Permainan}

Permainan handdball merupakan permainan modifikasi sepak bola dan bola basket untuk anak Sekolah Dasar kelas atas. Permainan dilakukan menggunakan sebagaian besar peraturan bola basket namun alat yang digunakan diambil dari permainan sepak bola dan cara mainnya seperti bola basket.

\section{Asal Permainan}

Pemilihan nama permainan handball berasal dari: Hand diambil dari nama depan permainan bola basket karena permainannya menggunakan lempar, tangkap dan dribel seperti permainan bola basket. Ball diambil dari nama belakang permainan sepak bola karena alat yang digunakan sebagaian besar permainan sepak bola.

\section{Aturan 1. Jumlah Pemain}

Permainan handdball menggunakan pemain yang berjumlah 8 orang. Posisi pemain dalam permainan ini adalah posisi 1 sampai dengan 3 , ada pun nama masing-masing posisi adalah: (1) Posisi 1: 1 Penjaga gawang, (2) posisi 2: 3 Pemain bertahan, (3) posisi 3: 2 pemain tengah, (4) posisi 4: 2 pemain penyerang.

\section{Aturan 2. Definisi Istilah}

Ukuran bola adalah lingkaran bola yang digunakan dalam permainan yang diukur dalam satuan $\mathrm{cm}$. Lapangan adalah tempat bermain dengan bentuk persegi empat dengan ukuran panjang 10 meter dan lebar 5 meter.

Garis adalah garis pembatas permaian yang berbentuk persegi empat dengan panjang 10 meter dan lebar 5 meter. Garis yang berada di dalam lapangan ada 2 garis yang berbeda yaitu: (a) garis yang tidak ptus-putus adalah garis area penjaga gawang, (b) garis yang putus-putus adalah garis area penyerang dan daerah pertahanan.

Gawang adalah daerah terjadinya poin atau gol dengan ukuran panjang 1 meter, lebar 1 meter. Bola fair adalah bola pada awal permainan dimulai dibagi di tengah lapangan apabila terjadi gol bola dibagi di tengah lapangan kembali.
Pelatih adalah seorang yang bertanggung jawab atas tindakan regu di lapangan. Dalam permainan ini pelatih diperankan oleh guru Penjasorkes dan olahraga. pemain bertahan adalah pemain yang menahan lawan menyerang mencetak gol.

Sebuah bola yang dilempar ke dalam secara tidak sah terjadi ketika lemparan saat lemparan sah atau salah dalam keadaan; (a) kaki pelempar menginjak garis atau masuk dalam lapangan, (b) apabila lemparan ke dalam menggunakan kedua tangan.

Line up adalah sebelum permainan dimulai untuk mempertemukan kedua regu. Pemain pengganti adalah pemain yang harus ikut bertanding untuk menggantikan seorang pemain yang harus meninggalkan pertandingan. Pemain pengganti yang di perbolehkan adalah: (a) seorang pengganti yang terdaftar yang belum bermain atau (b) seorang pengganti yang telah terdaftar dalam pemain tetapi kemudian diganti. Time adalah istilah yang digunakan oleh wasit untuk menghentikan sentara permainan.

\section{Aturan 3. Bidang Bermain}

Lapangan permainan menggunakan lapangan sepak bola dengan lantai tanah yang pada saat hujan lapangan kelihatan becek. Garis yang membatasi daerah permainan di antaranya: (a) garis persegi empat dengan ukuran panjang 10 meter dan lebar 5 meter, (b) garis tengah pembagi setengah lapangan dengan ukuran 5 meter dari gawang, (c) garis putus-putus dengan setengah lingkaran dengan jarak 3 meter, daerah peyerangan bagi lawan yang mencetak gol atau poin, (d) garis yang tidak putus-putus dengan setengah lingkaran dengan jarak 2 meter, daerah penjagaan bagi tim yang menghalangi terjadinya gol atau poin.

Gawang dengan ukuran tinggi 1 meter dan lebar 1 meter,gawang ini terjadinya poin. Daerah pinalti berada di garis dengan jarak 3 meter.

\section{Aturan 4. Peralatan}

Gawang terbuat dari paralon dengan ukuran 2'in. Bola menggunakan bola yang terbuat dari plastik yang tidak membahayakan mengenai anak dengan ukuran diameter $50 \mathrm{~cm}$.

Semua pemain memakai seragam dengan warna yang sama. Seyogyanya memakai seragam yang menggunakan nomor punggungagar mudah di kenali dengan teman tim. Namun peneliti untuk membedakan warna seragam yang tim A menggunakan rompi dan tim yang B 
menggunakan baju olahraga yang dari sekolah. Semua pemain harus memakai sepatu olahraga. Catatan: apabila keadaan siswa di SD banyak yang belum menggunakan sepatu atau kondisi lapangan basah maka pemain tetap dapat melaksanakan tanpa menggunakan sepatu.

Jalanya pertandingan diawali dengan wasit meniup peluit dan untuk memimpin jalannya pertandingan baik ada pelanggaran atau yang lain-lainnya. Waktu adalah bisa jam atau stopwatch, untuk membatasi pertmainan, karena dalam babak pertama 10 menit,dilanjut babak ke dua 10 menit. Jadi dalam pertanding 2x10 menit.

\section{Aturan 5. Pelatih, Pemain dan Pengganti}

Pelatih bertugas mengatur regu saat bertanding yang mencakup mengatur, memberi aba-aba saat permainan dilaksanakan.Pelatih dalam permainan ini diperankan oleh guru Penjasorkes Olahraga dan Kesehatan. Pelatih mengatur regu penyerang dan regu bertahan sekaligus.

Pemain dalam satu regu terdiri atas delapan pemain: penjaga gawang (1), pertahanan (2), penyerang (2), namun permainan ini bisa bergantain atau saling membantu dan yang tiga orang pemain pengganti. Jika pemain campuran maka lima pemain terdiri atas tiga putra dan dua putri, atau sebaliknya tiga putri dan dua putri. Catatan: pemain dari setiap tim di lapangan dapat ditempatkan di manapun di wilayah bertahan atau penyerang, kecuali penjaga gawang harus tetap di belakang dalam lingkaran daerah penjaga gawang.

Pemain awal adalah pemain yang telah disusun dan ditetapkan untuk permainan pertama. Prosedur pergantian pemain yaitu (1) pemain yang sedang bermain apabila mengalami kelelahan, ataupun mengalami cedera dapat digantikan oleh pemain cadangan yang masuk dalam daftar pemain. (2) Apabila pemain campuran maka pemain penganti harus dengan gender yang sama. (3) Pemain yang telah digantikan dapat masuk lagi selama permainan masih berlangsung.

\section{Aturan 6. Permainan}

Untuk menentukan regu yang membawa bola pertama dilakukan dengan cara di undi atau lempar koin yang menang membawa bola.

Lapangan yang digunakan dapat menggunakan lapangan dalam ruangan atau gedung ataupun rumput dan tanah selama keluasan mencakupi untuk dibuat lapangan bola tangan.
Peraturan Permainannya yaitu: (1) setiap tim wajib menggunakan kostum yang berbeda, (2) maksimal dribbel hanya tiga langkah untuk sekali dribbel, jika melebihi tiga langkah maka dilakukan lemparan ke dalam, (3) pemain bertahan atau penyerang tidak boleh memasuk dalam lingkaran, (4) jika pemain bertahan masuk ke dalam lingkaran, maka terjadi pelanggaran dan dilakukan lemparan pinalti, (5) jika peyerang masuk lingkaran maka terjadi pelanggaran dan dilakukan lemparan bebas, (6) tidak diperbolehkan melakukan body contact secara berlebihan, misalnya mendorong, menendang, menyikut, dan sebagainya. Jika hal itu terjadi maka akan dikasih peringatan pertama dan dilakukan lemparan bebas, (7) setiap kali bola mengenai kaki, baik disengaja ataupun tidak, maka terjadi pelanggaran, (8) penjaga gawang boleh menggunakan seluruh anggota badannya, dalam catatan selama dalam wilayah lingkaran, namun jika penjaga gawang keluar dari lingkaran maka terjadi pelanggaran.

Pemenang pertandingan adalah regu yang lebih banyak memasukkan hingga akhir pertandingan. Dalam penghitungan angka adalah memasukkan bola ke gawang.

\section{Aturan 7. Wasit}

Wasit memiliki wewenang memimpin dan mengatur jalannya pertandingan sesuai aturan yang berlaku. Wasit dalam permainan ini hanya satu wasit. Tanggung jawab wasit adalah memimpin pertandingan dan mengamati setiap permainan yang terjadi. Setiap penilaian wasit mutlak untuk diikuti. Seorang wasit dapat menunda pertan-dingan dengan ketentuan seorang wasit dapat menggunakan pertandingan jika dinilai perlu untuk dihentikan sementara, dan wasit tidak menunda permainan atas permintaan seseorang pemain.

\section{SIMPULAN DAN SARAN}

\section{Simpulan}

Telah terbentuk permainan bola tangan yang sesuai dengan karakterisitik anak kelas atas. Permainan ini terbukti efektif dengan adanya validasi ahli yang menyatakan bahwa model telah sesuai dan teruji diterima oleh respon murid terhadap permainan bola tangan yang dikembangkan.

\section{Saran}

Berdasarkan hasil penelitian dan pengembangan yang dilakukan agar model permainan bola tangan yang dikembangkan dapat diguna- 
kan sebagai salah satu bentuk pengajaran pendidikan jasmani disekolah maka dibutuhkan peran para guru penjas serta murid itu sendiri untuk meningkatkan kesedaran dalam mengenal permainan bola tangan dengan model pengembangan ini

\section{DAFTAR PUSTAKA}

Paturusi, A. (2012). Manajemen pendidikan jasmani dan olahraga. Jakarta: Rineka Cipta.

Bahagia, Y. (2010). Pengembangan fasilitas dan perlengkapan penjas untuk aktivitas permainan. Diakses dari: http://file.upi.edu/Direktori/F\% 20\%20FPOK/JUR.\%20PEND.\%20OLAH RAGA/194903161972111 $\% 20 \% 20$ YOYO\%20BAHAGIA/TERG ETNET\%20FASILITAS\%20\%26\%20P $\% 20 \mathrm{P} \% 0 \% 28 \mathrm{TERGETNET} \% 29 / \mathrm{M}-$ 6.pdf. Waktu akses: Tanggal 14 Maret 2011, pukul 13. 46 WIB.

Bahagia, Y., \& Suherman, A. (2000). Prinsipprinsip pengembangan dan modifikasi cabang olahraga. Jakarta: Depdikbud Borg, W. R. \& Gall, M, D. (1983). Educational research: An introducition, 4 edition new York dan London: logma.

BSNP. (2009). Standar kompetensi dasar sekolah dasar/madrasa ibtidaiyah mata pelajaran pendidikan jasmani olahraga dan kesehatan. Jakarta: Depdiknas.

BNSNP. (2006). Standar kompetensi dan kompetensi dasar pendidikan jasmani, olahraga dan kesehatan sekolah dasar dan madrasah ibtidaiyah. Jakarta: BNSNP.

Capel, S., \& Piotrowski, S. (2001). Inssues in physical education. USA and Canada: Routledge Falmer.

Chandler, T., Cronin, M., \& Vamplew, W. (2007). Sport and physical education. The key concepts, 2nd edition. USA and Canada: Routledge.

Desmita. (2012). Psikologi perkembangan peserta didik. Bandung: Remaja Rosdakarya.

Rosdiani, D. (2012). Model pembelajaran langsung dalam pendidikan jasmani dan kesehatan. Bandung: Alfabet.
Susanto, E. (2005). Diktat metodik bola tangan sebuah pengantar dalam pembelajaran. Jurusan pendidikan olahraga fakultas ilmu keolahragaan Universitas Negeri Yogyakarta.

Rahyubi, H. (2012). Teori-teori belajar dan aplikasi pembelajaran motorik. Bandung: Nusa Media.

Rahman, H. A. \& Susanto, E. (2007). Bola tangan sebuah pengantar dalam pembelajaran. Perpustakaan Nasional: Katalog dalam Terbitan (KDT). Yogyakarta

International Handball Federation. (2010). Diakses dari: http//www.ihf.info/history of handball. 1 Juli 2010.

Mahendra, A. (2000). Bola tangan: Departemen Pendidikan dan Kebudayaan Direktorat Jendral Pendidikan Dasar dan Menengah Bagian Proyek Penataran Guru SLTP Strata D-III.

Metzler. (2011). Instructional model for physical education. Arizona: Holcomb Hathaway, Publishers, Inc.

Lee, A. M., Thomas, K. T., \& Thomas, J. R. (2000). Physical Education For Children daily lesson plans for elemtary school, $\left(2^{\text {nd }}\right.$ Edition). USA: Human Kinestics.

Rukmana, A. (2008). Pembelajaran penidikan jasmani di ekolah dasar. Bandung: UPI. Jurnal penidikan dasar nomor 9 April 2008.

http://file.upi.edu/Direktori/jurnal/pendi dikan_dasar/Nomor_9April_2008/Pemb elajaran Pendidikan Jasmani di Sekol ah_Dasar.pdf. Diambil 17/12/2013.

Lutan, R. (2001). Olahraga dan etika fair play. Jakarta: Depdiknas.

Sagala, S. (2012). Konsep dan makna pembelajaran. Bandung: Alfabeta.

Suharjana. (2013). Kebugaran Jasmani, Jogja Global Media.

Yusuf LN, S,. (2012). Psikologi perkembangan anak \& remaja. Bandung: PT. Remaja Rosdakarya. 